\title{
Sentra Kerajinan Tenun Riau
}

\author{
Sholihindra ${ }^{1}$, Rika Cherish ${ }^{2}$, Repi $^{3}$ \\ 1,2,3 Program Studi Arsitektur, Fakultas Teknik, Universitas Lancang Kuning \\ Jl. Yos Sudarso km. 8 Rumbai, Pekanbaru, Telp. (0761) 52324 \\ Email: Indrasolihindra@yahoo.co.id, rika.cherish@unilak.ac.id, repi@unilak.ac.id
}

\begin{abstract}
ABSTRAK
Kerajinan tenun songket merupakan salah satu kerajinan tradisional masyarakat Melayu Riau, yang pada zaman dahulu sering dibuat oleh anak-anak bangsawan dan hanya dipakai oleh kalangan kerajaan dalam lingkungan terbatas. Dengan perkembangan zaman yang lebih modern, kain tenun songket sudah digunakan oleh masyarakat luas. Adapun permasalahan selama ini yang dihadapi keterbatsan alat, sumber daya manusia dan pemasaran produk. Maka diperlukan wadah berupa pusat kegiatan untuk terus melestarikan kerajinan tradisional tenun songket agar tidak punah dan perlunya memberikan informasi kepada masyarakat untuk mengenal dan mempelajari berbagai macam motif ragam hias yang digunakan dalam kerajinan tenun songket. Diharapkan untuk dapat menjadi sarana edukasi dibidang seni budaya Kerajinan tenun untuk para pelajar, mahasiswa serta masyarakat umum agar dapat membantu mengenal sejarah dan informasi tentang perkembangan kerajinan Tenun, begitu juga untuk para seniman untuk mendalami kembali pengetahuan di bidang Kerajinan Tenun ini.
\end{abstract}

Kata Kunci : Sentra (pusat), Edukasi,Indrusti,Rekreasi dan Pameran.

\section{ABSTRACT}

The songket weaving craft is one of the traditional handicrafts of the Riau Malay community, which in ancient times was often made by noble children and only used by the royal circle in a limited environment. With the development of a more modern era, songket woven fabric is already used by the public. The problems so far faced keterbatsan tools, human resources and product marketing. So needed a container in the form of an activity center to continue to preserve the traditional craft of songket weaving so as not to become extinct and the need to provide information to the community to know and learn various motifs of ornamental decoration used in songket weaving craft. It is expected to be a means of education in the field of Arts and Crafts Weaving art for students, students and the general public in order to help know the history and information about the development of crafts Weaving, as well as for the artists to deepen knowledge in the field of Craft Weaving..

Keywords : Sentra (center), Education, Indrusti, Recreation and Exhibition

\section{PENDAHULUAN}

Kerajinan merupakan hasil aktivitas dan kreatifitas manusia dalam bentuk karya seni dan budaya yang sudah berkembang sejak dahulu kala. Masyarakat Indonesia secara umum sudah mengenal seni, budaya dan kerajinan yang disesuaikan dengan kebiasaan, keahlian dan kebutuhannya. Pengaruh alam, lingkungan serta rangsangan naluri alamiah mengakibatkan corak dan selera manusia menjadi berbeda, berupa adat istiadat dan kebiasaan masyarakat yang khas maupun dalam bentuk-bentuk motif kerajinan yang dihasilkan).

Menurut seorang ahli ekonomi Inggris Howkins (2001) kerajinan termasuk salah satu kelompok bidang pekerjaan dalam industri kreatif. Kerajinan termasuk dalam kelompok industri yang padat kandungan seni dan budaya. Dalam industri kreatif membutuhkan kreatifitas sebagai hal utama yang mengutamakan desain dalam setiap proses menciptakan sebuah produk. Adapun 
proses penciptaan nilai yang menjadi strategi pengembangan dalam sebuah kegiatan industri kreatif yaitu berupa kreasi, produksi, distribusi dan komersialisasi.

Kerajinan tenun songket merupakan salah satu kerajinan tradisional masyarakat Melayu Riau, yang pada zaman dahulu sering dibuat oleh anak-anak bangsawan dan hanya dipakai oleh kalangan kerajaan dalam lingkungan terbatas. Dengan perkembangan zaman yang lebih modern, kain tenun songket sudah digunakan oleh masyarakat luas.

Di kota Pekanbaru terdapat tempattempat kerajinan tenun songket diantaranya tenun Wan Fitri, kelompok tenun di kampung Wisata, tenun Ibu yati. Usaha yang dilakukan rumah sebagai tempat industri ( home industri ). Adapun permasalahan selama ini yang dihadapi keterbatsan alat, sumber daya manusia dan pemasaran produk. Maka diperlukan wadah berupa pusat kegiatan untuk terus melestarikan kerajinan tradisional tenun songket agar tidak punah dan perlunya memberikan informasi kepada masyarakat untuk mengenal dan mempelajari berbagai macam motif ragam hias yang digunakan dalam kerajinan tenun songket.

Berdasarkan rantai penciptaan nilai dalam industri kreatif yang disesuaikan dengan kegiatan yang diwadahi, maka adanya kegiatan industri sebagai kegiatan menciptakan suatu produk kerajinan, pemasaran sebagai proses promosi produk, rekreasi berupa wisata budaya kepada para pengunjung serta edukasi sebagai proses pelatihan kepada siswa dalam pengembangan kreativitas untuk pelestarian kerajinan tenun.

Industri kreatif dari tenun songket bisa di buat bermacam-macam bentuk souvenir, mulai dari harga yang paling murah hingga harga tenun songket yang mahal. Hal inimenjadi salah satu aspek peningkatan ekonomi masyarakat dan secara tidak langsung menjadi souvenir wisatawan yang ada di Pekanbaru.

Dalam judul ini topik yang digunakan adalah Arsitektur Analogi Ekspresionis. Arsitektur analogi ekspresionis dinilai menjadi suatu sarana yang digunakan oleh arsitek untuk mengemukakan bahasanya terhadap karya bangunan yang di rancang. Perancangan ini pada dasarnya mengambil sebuah objek atau benda, dan kemudian akan dijadikan sebagai dasar bentuk perancangan.. Sehingga, topik ini bisa diterapkan pada sentra kerajinan tenun berubah menjadi tempat industri, edukasi ,pemasaran dan rekreasi, yang bernuansa modren .

\section{METODE PENELITIAN}

Metoda yang digunakan untuk mendapatkan data-data yang terkait dengan perencanaan dan perancangan Sentra ini adalah sebagai berikut:

\section{Studi Literatur}

Mengumpulkan dan menelaah data dari perpustakaan berupa karya ilmiah tugas akhir mahasiswa arsitektur serta buku-buku yang terkait dengan perencanaan dan perancangan mengenai Sentra.

\section{Studi Empiris}

Melakukan pengumpulan data serta referensi yang sejenis terkait dengan bangunan "Sentra Kerajinan Tenun Riau" baik secara langsung maupun tidak langsung, melalui internet, majalah, artikel seperti Sentra Kerajinan Tenun di palembang,.

\section{Studi Lapangan}

Melakukan peninjauan ketempat-tempat yang mencakup persamaan data sejenis dengan perancangan "Sentra di Pekanbaru".

\section{Wawancara}

Melakukan data dengan cara menanyakan secara langsung kepada sumber informasi dengan mengajukan beberapa pertanyaan kepada pihak terkait yang berhubungan dengan judul.

\section{HASIL DAN PEMBAHASAN}

\section{Sentra :}

Pusat, tengah, mengandung pengertian suatu bentuk kesatuan koordinasi dari aktivitas yang merupakan induk dari suatu rangkaian aktivitas dengan satu tujuan. (Kamus Besar Bahasa Indonesia) 


\section{Kerajinan :}

Barang yang dihasilkan melalui kerajinan tangan

Tenun :

Kata Tenun, menurut Kamus Besar Bahasa Indonesia, berarti hasil kerajinan yang berupa bahan (kain) dibuat dari benang (kapas, sutra, dan sebagainya) dengan cara memasukmasukan pakan secara melintang pada lungsi (benang yang membujur

\section{Pekanbaru :}

Adalah salah satu Kabupaten kota yang ada di Provinsi Riau

Dari pengertian diatas maka sentra kerajinan tenun Riau di Pekanbaru dapat didefinisikan sebagai berikut:

Suatu tempat pusat kegiatan yang mewadahi aktivitas pameran, pelatihan, pemasaran dan penjualan yang berkaiatan produk tenun dan benda-benda kerajinan tangan di Pekanbaru.

\section{Arsitektur Analogi Ekspresionis}

Arsitek Ekspresionisme merupakan bagian dari Analogi Linguistik. Dalam hal ini bangunan dianggap sebagai suatu wahana yang digunakan arsitek untuk mengungkapkan sikapnya terhadap proyek bangunan tersebut. Ekpresi bangunan dapat mengungkapkan keadaan, lokasi, konstruksi, pemakai, fungsi dan lainny,. arsitek menggunakan 'bahasa'nya pribadi (parole), bahasa tersebut mungkin dimengerti orang lain dan mungkin juga tidak. Penganut paham ekspresionisme memiliki dalil bahwa "Art is on expression of human feeling" atau seni adalah suatu pengungkapan dari perasaan manusia.

\section{Tinjauan Terhadap Gambaran Umum Kota Pekanbaru}

Pekanbaru adalah ibukota provinsi riau, berdasarkan peraturan pemerintah Nomor 19 tahun 1987 luas kota pekanbaru adalah 446,50 $\mathrm{km}^{2}$. Pekanbaru mempunyai 12 kecamatan dengan total keseluruhan sebanyak 58 kelurahan.

Iklim kota Pekanbaru ialah tropis lembab dikarenakan dilewati garis khatulistiwa, rata-rata suhu kota pekanbaru berkisar antara $24-31^{\circ}$ C. Sedangkan jenis tanah pada kota Pekanbaru ialah berjenis tanah alluvial yang berasal dari endapan tanah liat asosiasi alluvial dengan pasir. Pada daerah tinggi sebagian berjenis podsolik merah kuning sedangkan daerah yang lebih rendah berawa dan bergambut.

\section{Tinjauan Terhadap Lokasi Sentra Kerajina Ttenun Riau}

Adapun kriteria pemilihin lokasi pada Sentra krjainan tenun riau ini adalah sebagai berikut:

A.Tujuan Objektif

Untuk dapat menemukan dan menyelesaikan planning, programming dan konsep dasar perancangan.

B.Tujuan Subjektif

Agar dapat mewadahi semua kegiatan yang berkaitan dengan pusat kerajinan tenun Riau di Pekanbaru

\section{Lokasi Terpilih}

Lokasi terpilih terletak di Jalan Pesisir dengan luas $15.000 \mathrm{~m}^{2}$. Lokasi ini merupakan lokasi bangunan sekitaran pusat pemerintahan .

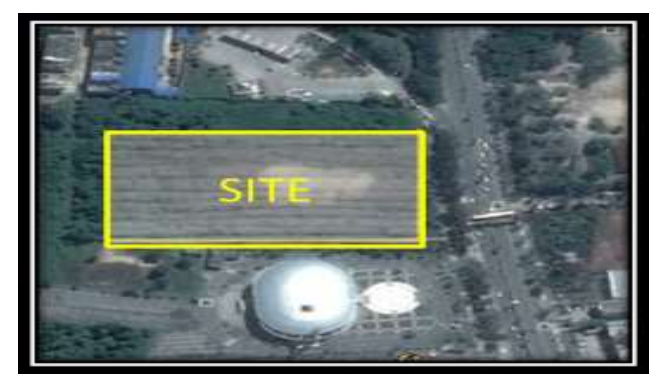

Gambar 1. Lokasi Terpilih Sentra Kerajinan Tenun Riau

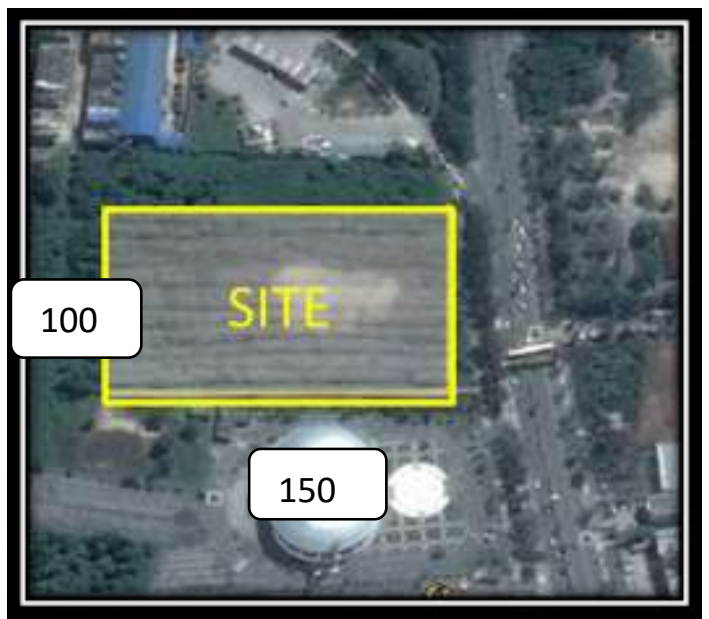

Gambar 2. Lokasi Site 
Berikut adalah keterangan dari

a. Nama Jalan: Jl.Jendral Sudirman

b. Kecamatan : Pekanbaru

c. Kota

: Pekanbaru

d. Provinsi

: Riau

e. Ukuran Tapak

$: 15.000 \mathrm{~m}^{2}$

f. WP-I

: Jl. Jendral Sudirman

\section{Batas-batas pada tapak}

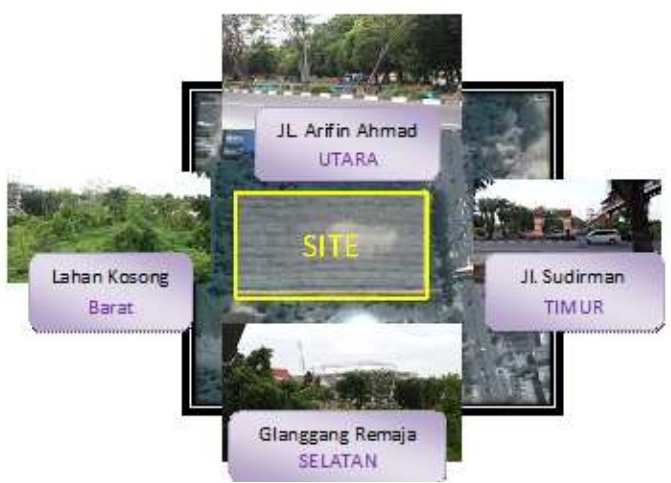

Gambar 3. Batasan pada kondisi tapak

a. Batas Tapak Sebelah Utara ialah Jl.Arifin Ahmad

b. Tapak sebelah selatan gedung Glangngang Remaja

c. Tapak sebelah barat ialah lahan kosong

d. Tapak sebelah timur Jl.Jendral Sudirman

\section{Aksessibilitas pada tapak}

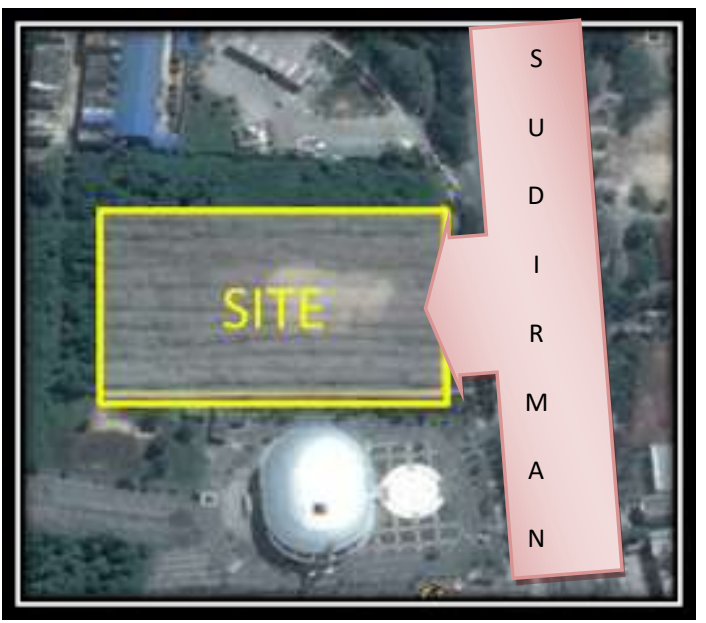

Gambar 4. Aksessibilitas pada tapa
Pencapaian pada tapak dapat diakses melalui transportasi umum dan pribadi seperti mobil pribadi, taxi, bus kota atau mini bus, sepeda motor dan sepeda, selain itu terdapat juga jalur pedestrian bagi pejalan kaki.

\section{Kondisi pada tapak}

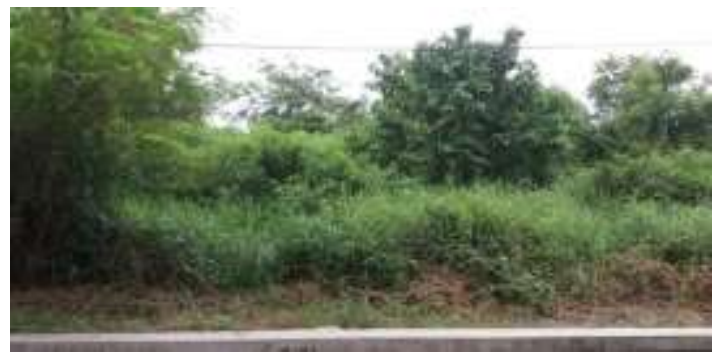

Gambar 5. Kondisi Tanah

Kondisi tanah pada Site yang cenderung datar dan tidak berkontur. Situasi ini memudahkan pengolahan bentuk bangunan dan pengolahan Jalur sirkulasi bagi kendaraan yang melintas diarea bangunan.

\section{Orientasi Matahari}

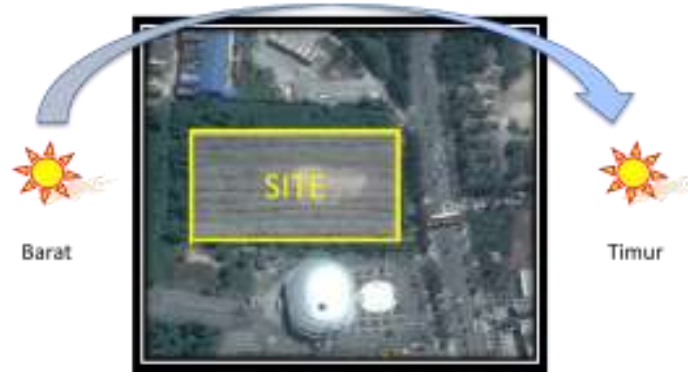

Gambar 6. Orientasi Matahari

Orientasi matahari pada tapak terjadi pada sisi sebelah timur dan barat, maka dari itu perencanaan bangunan pada tapak akan digunakan sun shading agar menghindari panas yang berlebih yang masuk kedalam bangunan.

\section{Sumber Kebisingan}

Untuk menghindari pengaruh dari tingkat kebisingan maka massa dari perencanaan bangunan diletakkan jauh dari 
sumber kebisingan. Sumber kebisingan tertinggi berada di jalan Jendral Sudirman. Selain itu pepohonan yang telah ada akan tetap dipertahankan sebagai buffer sehingga pengaruh kebisingan dapat diminimalkan.

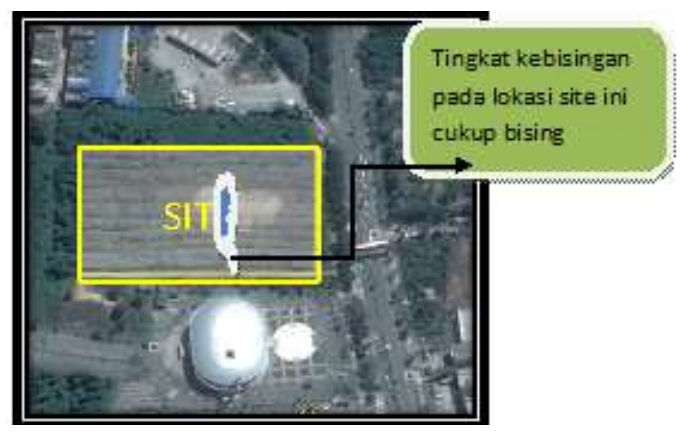

Gambar 7. Sumber Kebisingan

View pada tapak

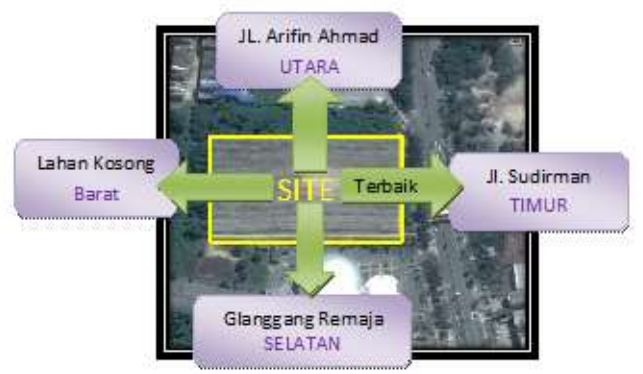

Gambar 8. View pada tapak

Lokasi tapak yang berada tepat dipinggir jalan ini membuat posisi tapak terlihat jelas. Pada jalan utama yaitu jalan Jendral Sudirman memiliki kualitas potensi yang baik dari pandangan luar menuju tapak dan.

Maka dari itu orientasi dari perencanaan bangunan lebih dipusatkan kepada arah jalan Jendral Sudirman dan yang kedua dari arah jalan Arifin Ahmad

\section{Analisa regulas}

A.Koefesien Dasar Bangunan

\begin{tabular}{|c|c|c|c|c|c|c|c|c|}
\hline $\mathrm{K}_{0}$ & Nina haghtage & Manda & fadilin & Nolvatiun & friam & hobaye & ntati & llasin \\
\hline & (v) & (\$) & (10) & (1) & (1) & 6i & $N$ & 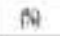 \\
\hline 1 & NPI & 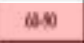 & (24) & Sth & $\pi N$ & $x \times 8$ & 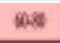 & 0 \\
\hline 2 & we & 52:10 & $8-11$ & 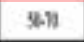 & 40 & 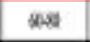 & oull & 0 \\
\hline 3 & v日 & 48 & 40 & sin & sh & Sa & out & 0 \\
\hline 4 & PN & 540 & san & \$8: & sh & $\alpha 40$ & wed & $x$ \\
\hline 5 & spr & 590 & แง & 367 & asd & $\Delta x$ & 30 & 804 \\
\hline
\end{tabular}

B. Koefesien Lantai

\begin{tabular}{|c|c|c|c|c|c|c|c|c|}
\hline$N$ & Wilog fagatiage & Nenitur & Anditin & faboura & Praxea & habrager & betari & Intin \\
\hline & (v) & (ntas) & (indola) & (ndate) & (nith) & (nds)en & (indes) & (ntaio) \\
\hline 1 & WFI & $190-2 \pi$ & $1060-160$ & $491-0 \pi$ & $a x-20$ & $07-2 \pi$ & $20 x-0.50$ & . \\
\hline 1 & מPI & $198-1,00$ & $0.56-610$ & $49-0 \%$ & 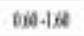 & $600+100$ & Q00-061 & + \\
\hline 3 & WPII & $40.1 x$ & 020.60 & $-400-a x$ & $200-6 \pi$ & $69-4 x$ & Q20.060 & . \\
\hline 4 & WPN & 195-10 & 080.67 & $450-0 \pi$ & 0.50 .167 & 6980-180 & 020.0ต & 63.10 \\
\hline 3 & SPY & $198-1 / 40$ & $0.80 \cdot 14)$ & $691-2 \pi$ & (200.-26) & $66-100$ & aखी- & 023.40 \\
\hline
\end{tabular}

C. Garis Sempadan Bangunan

\begin{tabular}{|c|c|c|c|c|}
\hline No & Jenis & Sempuim & Scripadan & Sempadan \\
\hline & Rougunati & Musa (m) & Bslakang (m) & Samping (m) \\
\hline 1 & Penmahan & 3.6 & $15-3$ & 1.4 \\
\hline 2 & Pendiskan & $10-12$ & $6-8$ & $3-4$ \\
\hline 3 & Keschatan & $8-10$ & 5.7 & $25 \cdot 3$ \\
\hline 4 & Ptribadalin & $4-20$ & $2 \cdot 4$ & 4.6 \\
\hline 5 & Perkuntaran & 1.8 & 3.4 & 3.4 \\
\hline 6 & Perdagangan & $4-20$ & $4-6$ & $3-4$ \\
\hline 7 & Inthustri Guadanef: & $20-40$ & 20.60 & $10 \cdot 30$ \\
\hline
\end{tabular}

perancangan dengan tema pendekatan Analogi Ekspresionis. maka saya akan menjelaskan maksud dari konteks Analogi Ekspresionis itu sendiri lewat ciri-ciri konsep

Salah satu nya yaitu bangunan memiliki bentuk dasar dan ornamen melayu pada bangunan yang akan di rancang agar sesuai dengan konsep analogi ekspresionis itu sendiri

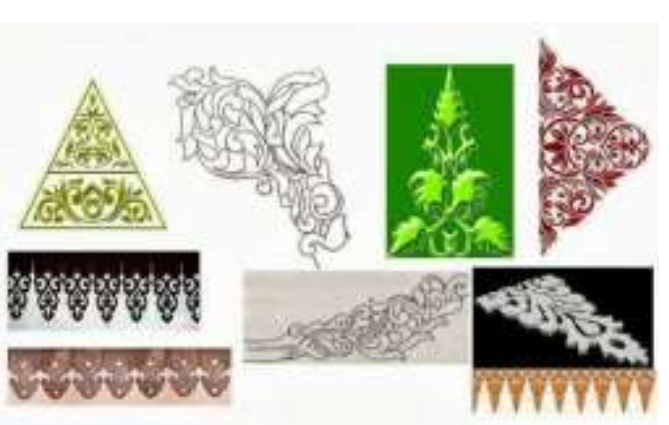

Gambar 9. Kosep Ornament Rumah Melayu

\section{Konsep Bentuk Dasar bangunan}

Seperti yang telah saya jelaskan bahwa konsep dasar perancangan berdasarkan Tema. Maka Konsep bentuk dasar dan gubahan massa bangunan itu mengambil Transformasi 
dari bentuk alat penenun songket salah satunya alat penggulung benang emas .

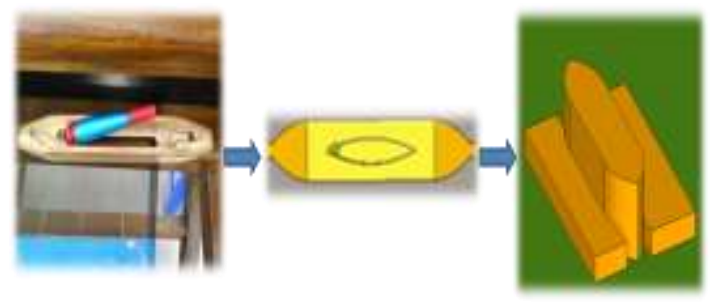

Gambar 10. Aat penggulung benang emas

Selanjutnya bentuk tersebut akan saya transformasikan untuk kemudian menjadi bentuk dasar dan gubahan massa bangunan untuk mesimbolkan karakter yang berbentuk alat penggulung emas.

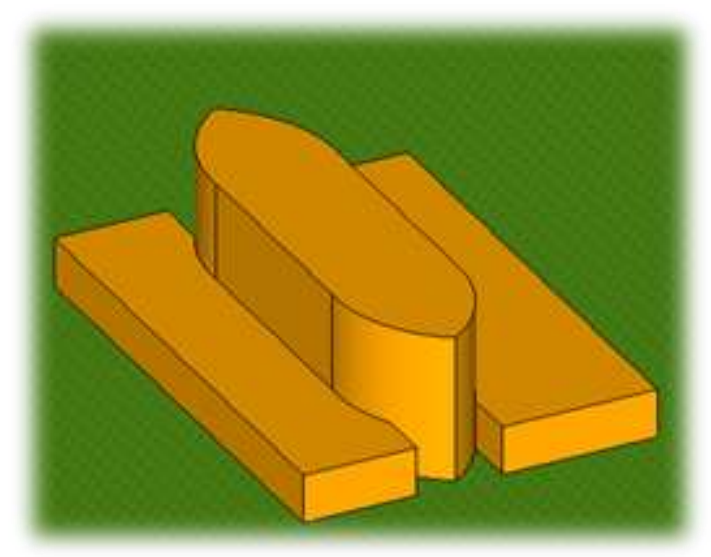

Gambar 11. Bentuk Gubahan Masa

Maka selanjutnya adalah Proses transformasi bentuk dasar bangunan dari bentuk kapal menjadi bentuk dasar bangunan.

\section{Konsep Pada Tapak}

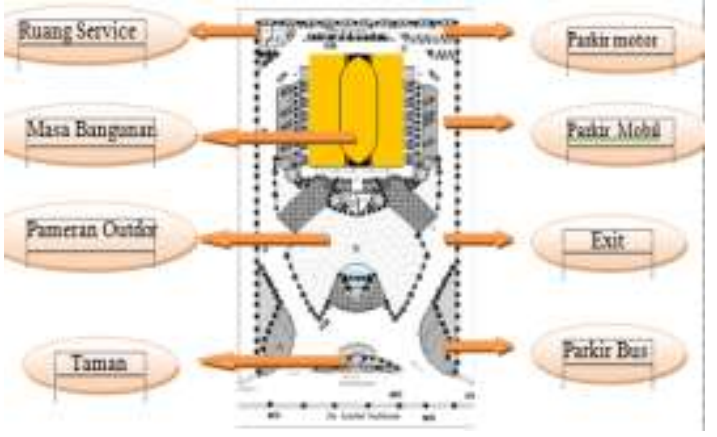

Gambar 12. Penzoningan Tapak

Konsep pola sirkulasi pada tapak merupakan pola sirkulasi linier yang dinamis, yang terbentuk akibat penzoningan. Entrance kedalam tapak terletak pada bagian sisi kanan depan tapak, dan pintu keluar dari tapak terletak pada bagian sisi kiri depan tapak.

\section{KESIMPULAN DAN SARAN}

Sentra Kerajinan Tenun di Pekanbaru ini adalah perancangan sebuah tempat yang memiliki fasilitas-fasilitas dengan sifat terbuka yang melayani kebutuhan publik untuk kebutuhan edukasi, rekreasi, industri dan pameran

Topik yang di ambil dalam perancangan Sentra Kerajinan Tenun Riau ini adalah Arsitektur Analogi Ekspresionis yaitu suatu teori yang berpandangan bahwa sebuah bangunan ditujukan untuk menyampaikan suatu hal kepada para orang yang mengamatinya, juga untuk menggambarkan bagaimana nilai-nilai tersebut dapat dituju dengan membatasi unsur-unsur pada bentuk yang bermanfaat serta kemudian dapat diperindah. Tema pendekatan Pendekatan rancangan terhadap nilai-nilai arsitektur Melayu.

Skala dalam Perencanaan perancangan Sentra Kerajinan Tenun di Pekanbaru adalah tingkat Kota yang meliputi Sejarah, Budaya dan Seni Melayu. 


\section{DAFTAR PUSTAKA}

[1] Ching,D.K, Francis.1985, Arsitektur:Bentuk-Ruang dan Susunannya,Jakarta : Erlangga

[2] Al Mudra, Mahyudin, 2004. Rumah Melayu : Memangku Adat Menjemput Zaman, Yogyakarta: Adicitra

[3] Amanati, Ratna. 2008. Transformasi Makna Dalam Tampilan Visual Arsitektur Theme Park. Jurnal Sains Dan Teknologi Universitas Riau. 7: 4553.

[4] Kusnadi, 1983. Peranan Seni Kerajinan (Tradisional dan Baru) Dalam Pembangunan, Jakarta: Astri Asri.

[5] Malik, Abdul; Effendy, Tenas; Junus, Hassan; Thaher, Auzar. (2004). Corak dan Ragi Tenun Melayu Riau. Yogyakarta: Adicitra. 